\title{
Anatomiye Işık Tutan Kadın: Anna Morandi Manzolini*
}

\author{
The Woman Shedding Light on Anatomy: Anna Morandi Manzolini \\ Berfu Özdemiri, Onur Can Şanlıi, Ahmet Dursuniii
}

'Yüksek Lisans Öğr., Süleyman Demirel Üniversitesi Tıp Fakültesi, Anatomi AD., https://orcid.org/0000-0001-5851-0300

iiMSc., Süleyman Demirel Üniversitesi Tıp Fakültesi, Anatomi AD., https://orcid.org/0000-0003-4225-0000

iiiDr. Öğr. Üyesi, Süleyman Demirel Üniversitesi Tıp Fakültesi, Anatomi AD., https://orcid.org/0000-0003-4568-8761

öz

Amaç: Tarih boyunca kadınlar, yasaklansa ya da toplum tarafından hoş görünmese bile bilimin içinde yer almış ve tüm bu engellemelere rağmen önemli işlere imzalarını atmışlardır. Bu kadın bilim insanlarından biri olan Anna Morandi Manzolini'nin (17161774) sağlık alanında çalışmamasına ve toplumun görüşlerine rağmen, yaptığı çalışmalar ve eserler ile anatomi biliminin gelişmesine çok önemli katkıları olmuştur. Bu nedenle Anna Morandi Manzolini'nin hayatını ve başarılarını açıklığa kavuşturmayı amaçladık.

Yöntem: Kitaplar ve ilgili literatür taranarak Anna Morandi Manzolini'nin akademik hayatı ve anatomi bilimine katkılarıyla ilgili veriler elde edilmiştir.

Bulgular: Morandi'nin statüsü, anatomist ve sanatçı olarak eş zamanlı rolü nedeniyle karmaşıktır. Morandi, doku ve organların doğru mum modellerinin önde gelen yaratıılarından biridir. Morandi'nin bal mumları, insan vücudunun işleyişini gerçekçi bir şekilde ortaya koymak ve teorileştirmek için güzel sanatlar ve cerrahiyi birleştirerek pratik görsel ile teorik metin arasında köprü kurmaktadır. Birçok buluş ve yeniliklere imza atan Morandi'nin bilinen ilk kadın anatomist olması ilgi çekicidir.

Sonuç: Morandi, bal mumu modeli için yeni bir amaç oluşturmuş, bu modelleri doğru anatomi için bir öğretim aracı olarak sunmuştur. Bal mumu modellerini, sistematik bir yaklaşımla aşamalı diseksiyona dayalı 250 sayfalık bir defter olarak düzenlemiştir. Bu defterin ve eserlerinin çağdaş anatomik çalışmaların gelişimi üzerindeki etkileri oldukça büyüktür.

Anahtar Kelimeler: Kadın anatomist, Bal mumu modeli, Anatomi eğitimi, Diseksiyon

\section{ABSTRACT}

Objective: Throughout history, women have been involved in science, even if they were banned or disliked by society, and despite all these obstacles, they have achieved important works. Despite the opinions of the society and not working in the field of health, the studies and works of Anna Morandi Manzolini (1716-1774), one of these women scientists, made very important contributions to the development of anatomy science. Therefore, we aimed to clarify the life and achievements of Anna Morandi Manzolini.

Method: Data on Anna Morandi Manzolini's academic life and contributions to science were obtained by scanning the books and related literature.

Results: Morandi's status is complicated by her concurrent role as an anatomist and artist. She is one of the leading creators of accurate wax patterns of tissues and organs. Morandi's waxes bridge the gap between practical visual and theoretical text by combining fine arts and surgery to realistically reveal and theorize the functioning of the human body. It is interesting that this person who made such inventions and innovations was the first known female anatomist.

Conclusion: Morandi set a new purpose for the wax model, presenting it as a teaching tool for correct anatomy. She organized the wax models as a 250-page notebook based on gradual dissection with a systematic approach. The effects of this notebook and her works on the development of contemporary anatomical studies are enormous.

Keywords: Woman anatomist, Beeswax model, Anatomy education, Dissection

\footnotetext{
*Lokman Hekim Dergisi, 2021; 11 (2): 204-211

DOI: $10.31020 /$ mutftd.879300

e-ISSN: 1309-8004, ISSN 1309-761X

Geliş Tarihi-Received: 12 Şubat 2021; Kabul Tarihi - Accepted: 22 Nisan 2021

Iletişim - Correspondence Author: Berfu Özdemir <ozdemir.berf@gmail.com>
} 


\section{Giriş}

Tarih boyunca kadınlar, yasaklansa ya da toplum tarafından hoş görünmese bile bilimin içinde yer almış ve tüm bu engellemelere rağmen önemli işlere imzalarını atmışlardır. Bu bilim insanlarının bazıları da tıp ile ilgilenmiş ve zaman içinde şifacı, ebe, doktor gibi unvanlar almışlardır. Yine birçok kadın bilim insanının da toplumun görüşlerine ve sağlık alanında çalışmamasına rağmen, yaptıkları çalışmalar ve eserler ile anatomi biliminin gelişmesine çok önemli katkıları olmuştur. ${ }^{1}$ Eğitim amacıyla üretilen bal mumundan yapılan en eski model, Sicilyalı sanatçı Gaetano Giuliano Zumbo tarafından XVII. yüzyılın sonunda yapılan anatomik kafadır. Zumbo, Bolonya'daki Bilim Enstitüsünde, ilk mum modelleme okulunda eğitim görmüştür. Eğitim amaçlı dikkat çekici anatomik modeller, XVIII. yüzyılda Bolonya Üniversitesinde Anatomi Müzesi'nin kurulmasına da yardımcı olan ünlü Bolonyalı ressam Ercole Lelli tarafından devam ettirilmiştir. ${ }^{2}$ Bu anatomik bal mumu modellerin üretiminde, Anna Morandi Manzolini (1716-1774) ve eşi Giovanni Manzolini (1700-1755), Lelli ile birlikte çalışmışlardır. ${ }^{3}$

Anna Morandi Manzolini'nin insan örnekleri ve bal mumu modelleriyle yenilikçi anatomi öğretisi, İtalya'da oldukça etkileyici olarak yorumlanmıştır. ${ }^{4-5}$ Anna Morandi, diseksiyon salonunun zorlu şartlarında tıp öğrencilerine anatomi anlatmıştır. ${ }^{6}$ Anatomik bal mumu modeller yaratmış, evindeki laboratuvarında organlar hakkında yazılar yazmış ve dersler vermiştir. ${ }^{7}$ Anna Morandi Manzolini'den bahsetmeden, kadınların anatomi biliminin gelişimi üzerine etkisi anlaşılmış sayılmaz. Bu nedenle Morandi'nin hayatının ve başarılarının sunulması ve tanınırlığının arttırılması amaçlanmıştır.

Çalışma 28.07.2020 ile 10.02.2021 tarihleri arasında gerçekleştirilmiştir. Çalışmada; Anna Morandi Manzolini ile ilgili bilgilere, literatürden ve tarihi kaynaklardan ulaşılmıştır. Bu kapsamda konu ile ilgili kütüphanelerde bulunan kitaplardan, PubMed ve Google Scholar üzerinden literatür taraması yapılmış, elde edilen bilgiler sunulmuştur. Bilgilerin kitaplar ve makaleler içerisinde yer almasına dikkat edilmiş, literatürde tutarsız olduğu düşünülen bilgiler çalışmaya dâhil edilmemiştir. Toplanan veriler kronolojik sıra dikkate alınarak makalemizde sunulmuştur.

Anna Morandi Manzolini'nin bal mumu çalışmalarının fotoğraflarının makalemizde kullanılabilmesi için 10 Şubat 2021'de Bolonya Üniversitesi Anatomi Müzesi'nden izin alınmıştır. Fotoğraflar Bolonya Üniversitesi Anatomi Müzesi tarafından tarafımıza gönderilmiştir. Anna Morandi'nin akademik hayatı ve bilime katkıları saptanarak elde edilen bulgular "Hayatı”, "Eğitimi”, "Anatomi Bilim Dalında Başarıya Ulaşma Süreci”, "Ulusal ve Uluslararası Başarıları”, "Eserleri”, "Etkileri” başlıkları altında sınıflandırılarak sunulmuştur.

\section{Hayatı}

Anna Morandi, 1716 'da İtalya'nın Bolonya kentinde doğmuştur. Ailesi Rose ve Charles Morandi'dir. Toplum tarafından kadının en önemli görevinin, çocuklarını büyütmenin ve aile yaşamının devamlıı̆ı̆ını sağlamanın uygun görüldüğü geleneksel bir evde büyümüştür. ${ }^{8}$ Anna Morandi, Bolonyalı sanatçı ve anatomist Giovanni Manzolini ile 1740 yılında evlenmiştir. ${ }^{9-10}$ Giovanni Manzolini'yle evlilik bağıyla başlayan ilişkileri zamanla meslektaşlığa dönüşmüştür. ${ }^{5}$ Çiftin uyumlu profesyonel iş birliği, anatomi bilimine ve sanatına çok büyük katkılar yapmıştır. ${ }^{10}$ Giovanni Manzolini, evliliklerinden sadece birkaç yıl sonra tüberküloz tanısı almıştır. ${ }^{8}$ Giovanni Manzolini 1755 'te akciğerlerinin su toplaması ve karaciğer yetmezliğinden öldüğünde Anna Morandi iki çocuğuyla kalmış ve ekonomik zorluklar çekmiştir. ${ }^{6,10}$ Kocası ile kendisinin, maddi destek sağlayabilecek zengin aileleri yoktu. Dul kaldığında, ekonomik zorluklar nedeniyle 11 yaşındaki oğlu Giuseppe'yi bir yetimhaneye yerleştirmiştir. ${ }^{6}$

Morandi, kocasının ölümünden sonra Papa olarak atanan asilzade Prospero Lorenzo Lambertini'den (Papa XIV. Benedictus) ömrü boyunca sürecek bir para yardımı talebinde bulunmuştur. Bal mumu koleksiyonunu satın almak isteyen yabancı ülkelerden teklifler aldığını belirtmiştir. Bolonya Senatosu'nun bir komitesi 
tarafından yapılan detaylı incelemenin ardından ünlü anatomik modellemelerini Bolonya'dan taşımaması ve üniversitede yıllık halka açık gösteri yapması şartıyla kendisine yıllık mütevazı bir para yardımı verilmiştir. ${ }^{3,10}$ Bolonya'daki kamu hastanelerinden teslim edilen binden fazla kadavrayı, evinden inceleme yetkisi verilmiştir. ${ }^{3}$ Bu erişim için Papa XIV. Benedictus'a çok şey borçludur. Papa XIV. Benedictus, papaların insan kadavralarının diseksiyonu konusundaki önceki kararlarını yeniden gündeme getirmiş ve bunu eğitim amacıyla yapmanın günah olmadığını savunmuştur. Ayrıca, kadınların eğitimini destekleyen görüşler sunmuştur. ${ }^{6}$ Daha sonra, kadınlar için kültürel alanda da yeni olanaklar açmıştır. ${ }^{4}$

\section{Eğitimi}

Anna Morandi, Giuseppe Pedretti (1694-1778) ve Francesco Monti'nin (1685-1768) stüdyolarında çizim ve heykeltıraşlık üzerine profesyonel eğitim almıştır. ${ }^{6,11}$

Morandi'nin herhangi bir tıbbi eğitimi ve diploması yoktur. ${ }^{3}$ Diseksiyonu, anatomik metinleri okuyarak öğrenmiştir. ${ }^{6}$ Enerjisini güçlü bir şekilde bal mumu modellemeye harcamıştır. Zaman, emek ve uzmanlık isteyen derin bir anatomi bilgi birikimine ulaşmasıyla, çalışmalarında anatomik ayrıntıları mükemmel bir şekilde göstermiştir. ${ }^{9}$

\section{Anatomi Bilim Dalında Başarıya Ulaşma Süreci}

Papa XIV. Benedictus'un hayali, bir anatomi müzesinin oluşturulmasıdır. ${ }^{3} 1742$ 'de Bolonya'da anatomik bal mumu modellerini yapan ilk ve en ünlü sanatçı, Ercole Lelli'dir. Ercole Lelli, ressam ve heykeltıraştır. ${ }^{4}$ Papalık komisyonu, Bolonya Üniversitesi'nde 1743'te kurulan Anatomi Müzesi için Ercole Lelli ile işbirliği yapmıştır. ${ }^{5,9}$ Papa XIV. Benedictus, anatomi müzesi projesi için cömert bir bağışta bulunmuştur. ${ }^{4}$ Anna Morandi ile genç bir asistan olan Giovanni Manzolini ilk olarak, anatomik bal mumu modellerinin üretimi projesinde Lelli ile birlikte üç yıl çalışmışlardır. ${ }^{3}$ Anna Morandi ve Giovanni Manzolini, cerrah Boari'nin yardımıyla, modellemelerindeki mükemmellikte, Lelli'yi geride bırakmışlardır. ${ }^{9}$ Daha sonra Lelli, Giovanni Manzolini ve Anna Morandi, Marsigliano Enstitüsü'nün Bilim Akademisi için bal mumu modelleri hazırlamışlardır. Bunların arasında, kas sistemi çalışmaları öne çıkmıştır. Erkek ve kadın kadavraları, ilk olarak bütünüyle göstermişler ve sonra diseksiyonla katman katman ilerleyerek, kemikli iskelete kadar indirgeyip seriyi tamamlamışlardır. Bu modelleri Anna Morandi, Giovanni Manzolini ve Lelli birlikte hazırlamışlardır. Ancak Anna Morandi ve Giovanni Manzolini, Lelli ile eşit derecede ünlü olmamışlardır. Aralarındaki bir anlaşmazlığın ardından Manzolini, Lelli'den ayrılmış ve ona yardım eden eşi Anna Morandi ile birlikte bal mumu modelleri hazırlamaya devam etmiştir. ${ }^{4}$ Morandi ve kocası, kendi evlerinde, diseksiyon odasıyla tamamlanan bir laboratuvar kurup anatomik diseksiyon ve insan vücudunu bal mumu yoluyla görselleştirme çalışmalarını sürdürmüşlerdir. ${ }^{5,9}$ Çift, özellikle kol ve göz yapısına yoğunlaşan bal mumu modellerini oluşturmuşlardır. Diseksiyon uygulanacak kadavraların temini yerel morglardan sağlanmıştır. Bu kadavraların vücut parçalarını, önce diseksiyonla kemiğe indirgemişler ve sonra bal mumundan yeniden inşa etmişlerdir. ${ }^{3}$

Giovanni Manzolini, Bolonya Üniversitesi'nde Anatomi Profesörü olarak görev yapmıştır. Otuz yaşında hastalanan Giovanni Manzolini, hastalıkla ve yaşam koşullarıyla baş etmekte zorlanmıştır. Anna Morandi kocasına işinde yardım etmiştir. Anna Morandi, bal mumu modelleri yapmanın yanı sıra kocasının yerine üniversitede anatomi dersleri vermiştir. Giovanni Manzolini, karısına ne kadar borçlu olduğunu şu sözlerle ifade etmiştir: "Beni kendime geri getirdi". Anna Morandi, eşi Giovanni Manzolini'yi, cesaretlendirmiş ve işine dönmesini sağlamıştır. ${ }^{8}$

Anatomi Profesörü Domenico Maria Gusmano Galeazzi, 1751'de Bolonya Üniversitesi'nin Archiginnasio Anatomik Tiyatrosu'nda (Archiginnasio Anatomical Theatre), daha popüler adıyla Karnaval Diseksiyonu (Carnival Dissection) olarak bilinen on dört günlük Genel Anatomi'yi (Public Anatomy) yönetmiştir. Giovanni Manzolini, etkinliğe katılan birçok kişiden biridir ve daha sonra bu etkinlikte kullanılan bir kadavrayı 
Galeazzi'den temin etmiştir. Otuz beş yaşındaki erkek kadavra, yaşamı boyunca sağır ve dilsizmiş. Manzolini ve Anna Morandi, adamın sessizliğinin sağırlı̆ının dolaylı sonucu olup olmadığını belirlemek için daha fazla anatomik inceleme yapmaya çalışmışlardır. Konuşma kaslarını, sinirlerini ve bileşen parçalarını incelemişler, defekt bulamamışlardır. Temporal kemiklerin ve kulağın anatomik kısımlarının tek tek incelenmesi sonucunda her iki kulağın işitme yapılarının büyük ölçüde bozuk olduğunu keşfetmişlerdir. Orta kulak kemikçiklerinin kaynaşmış, cochlea'nın tepesi (cupula cochleae) ve spirallerinin (canalis spiralis cochleae) bulunmadığını belirtmişlerdir. Sesin iletilmesini ve beyin tarafından yorumlanmasını engelleyen işitme yapısının defekte sahip olması da konuşmasının gelişmesini engellemiştir, diye ifade etmişlerdir. ${ }^{10}$ Çift, kulağın anatomisi ve sağırlık ile konuşamama arasındaki bağlantı hakkındaki araştırmaları için ünlü elektrofizyolog, anatomist ve deneysel fizikçi Luigi Galvani ve Gusmano Galeazzi ile birlikte çalışmışlardır. Anatomi ve Kimya Profesörü Jacopo Bartolomeo Beccari de çiftle doğrudan çalışmıştır. ${ }^{4}$

Anna Morandi'nin halka açık diseksiyonları, Bolonya Üniversitesi'nin tıbbi amfi tiyatrosundaki (Teatro Anatomico) derslerle birleştirilmiştir. Bu diseksiyonlardan elde edilen bilgileri mum modellerine aktarmış ve daha sonra bu modellerle insan anatomisini anlatmıştır. ${ }^{4}$

Evinde kadın hastalıkları okulu açan Jinekoloji Profesörü Giovanni Galli, Anna Morandi'yi ders vermek üzere okula davet etmiştir. Anna Morandi bu daveti kabul etmiştir. Derslerinde, insan anatomisine dair sahip olduğu teorik ve pratik uzmanlığı, bal mumu modellerini kullanarak açıkça göstermiştir. ${ }^{8}$

\section{Ulusal ve Uluslararası Başarıları}

Anna Morandi ve Giovanni Manzolini, Avrupa'daki birçok sanatçı, entelektüel ve anatomist tarafından bir ekip olarak bilinmiştir. ${ }^{8}$ Çift, tıp uzmanları, hevesli amatörler, Avrupa ve Rusya'nın Kraliyet Sarayları ve Bilim Akademileri için çeşitli anatomik modeller üretmişlerdir. Bu üretimleri hem kendi koleksiyonları için hem de ticari olarak sürdürmüşlerdir. ${ }^{6}$ Sardinya Kralı Charles Emanuel II, Napoli Kralı Charles ve Polonya Kralı Augustus III dâhil olmak üzere İtalya ve Avrupa'daki hükümdarlara bal mumu modelleri yapmışlardır. ${ }^{10}$ Anna Morandi, Giovanni Manzolini ile olan ortak bal mumu çalışmalarını, laboratuvarını ziyaret eden ziyaretçilere açmıştır. ${ }^{3,5}$ Anna Morandi'nin ev laboratuvarındaki anatomik gösterileri, kısa sürede Grand Tour'daki Avrupalı gezginlerin uğrak noktası haline gelmiştir. ${ }^{10}$ Anna Morandi, halka açık diseksiyonlar sunarken anatomi bilgisiyle şaşırtmış ve dikkatleri üzerine çekmiştir. ${ }^{3,5}$

Morandi ve kocası, on iki yıllık ortaklıkları boyunca, Londra Kraliyet Cemiyeti ve Venedik Savcısı için duyu organlarının bal mumu modellerini yaratarak uluslararası tanınırlık kazanmışlardır. Hekim Giovan Antonio Galli tarafından kurulan Bolonya'nın ilk kadın doğum okulu ve müzesi için kadın üreme sisteminin ve rahimin bal mumu modellerini yapmışlardır. Ayrıca Papa XIV. Benedictus tarafından atanan Bolonya'nın ilk Cerrahi Kürsüsü'nün başkanı Pier Paolo Molinelli için anatomik bal mumu modelleri yapmışlardır. ${ }^{10}$

Manzolini'nin ölümünden sonra Morandi bilimsel çalışmalarına devam etmiştir. Avrupa'nın her yerinden tıp doktorlarını ve turistleri çeken, anatomi gösterilerini yürütmüştür. ${ }^{10}$ Ünü Italya'dan Londra'ya ve Rus sarayına ulaşmıştır. ${ }^{5}$ Bir kadın için önemli bir onur olan Clementina Sanat Akademisi'nin fahri üyeliğine $1755^{\prime}$ de seçilmiştir. Böylece şehirde onurlandırılan, az sayıdaki kadın sanatçı arasına katılmıştır. ${ }^{3,9}$ Papa XIV. Benedictus tarafından üniversitede eğitim vermesine izin verilerek, Anatomi Kürsüsü’ne atanmıştır. ${ }^{9}$ Anatomi Profesörü unvanını 1756 'da almıştır. ${ }^{8}$ Bolonya Üniversitesi tarafından 1760 'ta Genel Modelci ve Anatomi Göstericisi olarak atanmıştır ve kendisine "Modellatrice" unvanı verilmiştir. ${ }^{10,12}$

Anna Morandi'nin bal mumu modelleri Bolonya'daki Bilim Enstitüsü Anatomi Müzesi'nde sergilenmiştir. ${ }^{3}$ Ayrıca, kılcal damarlar ve sinirler de dâhil olmak üzere küçük vücut kısımlarını bal mumunda gösteren ilk kişidir. ${ }^{8}$ Yerel bir sanatçı olarak, gerçekçi ve detaylı anatomik bal mumu modelleriyle uluslararası beğeni kazanmıştır. ${ }^{10}$ Anna Morandi'nin bal mumu modelleri koleksiyonu, tüm Avrupa'da "Supellex Manzoliniana" 
olarak bilinmektedir. Çok sayıda devlet başkanı tarafından onurlandırılmıştır. Avusturyalı II. Joseph onu ziyaret etmiş ve bir hükümdara verilenlere eş değer armağanlar vererek yaptığı işlere takdirini göstermiştir. Ayrıca Catherine II tarafından Rusya'da konferans vermek üzere davet edilmiştir. İtalyan Kraliyet Topluluğu, Rus Kraliyet Bilim Derneği ve İngiliz Kraliyet Cemiyeti üyeliğine seçilmiştir. Milano Üniversitesi, onu anatomi başkanı olarak atamak için istediği koşulları sunan boş bir sözleşme göndermiştir. Ancak Morandi'nin Bolonya sevgisi ağır basmış ve Bolonya'dan ayrılmamıştır. ${ }^{8}$

\section{Eserleri}

Anna Morandi Manzolini'nin bal mumu modelleri ince detaylı ve açıklayıcıdır. Bal mumu modellerini şekillendirmek için gerekli anatomi bilgisinde eşi Giovanni Manzolini'yi geride bıraktığı görülmüştür. ${ }^{3,8}$ Anna Morandi'nin bal mumu modelleri, daha çok insan vücudunun dinamik kısımlarını içerir. ${ }^{4}$ Şekil 1'den de anlaşılacağı üzere, vücuda ilişkin üç boyutlu anatomik imgeleri, modellerinde o kadar ustaca şekillendirmiştir ki, bal mumu modelleri kadavra parçalarının birebir kopyası gibi olmuştur. ${ }^{8,10}$

Anna Morandi Manzolini'nin çalışmaları, bal mumu modellerinin güzelliği ve anatomik doğruluğu ile ünlüdür. ${ }^{5,12}$ Özel uzmanlık alanları arasında iskeletin gelişimsel anatomisi, kadın ve erkek üreme sistemleri ve duyu organları vardır. ${ }^{5}$ Tüm duyu organlarının anatomisine ve fizyolojisine, fiziksel uyarana, sinir ve motor etkisine özel olarak odaklanmıştır. Morandi'nin yüzlerce bal mumu modeli hareketsiz bir vücudu yansıtmaktan çok bedeni yaşamda ve çoğu zamanda hareket halinde ifade etmiştir. ${ }^{10} \mathrm{Bu}$ model örneklerinden biri de Şekil 2'de görülmektedir. Bal mumu modelleri, hayattayken ve ölümünden sonra çok değerli hale gelmiştir. ${ }^{8}$

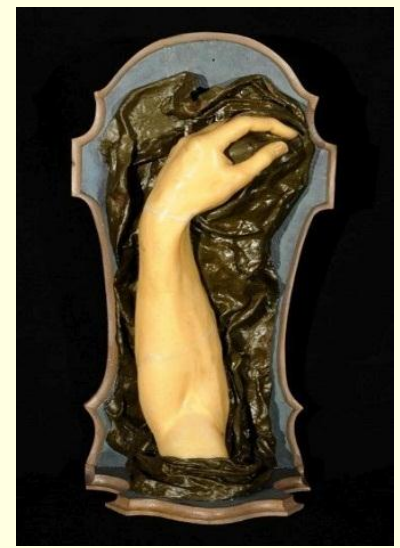

Şekil 1. Anna Morandi tarafından hazırlanan ön kol bal mumu modeli

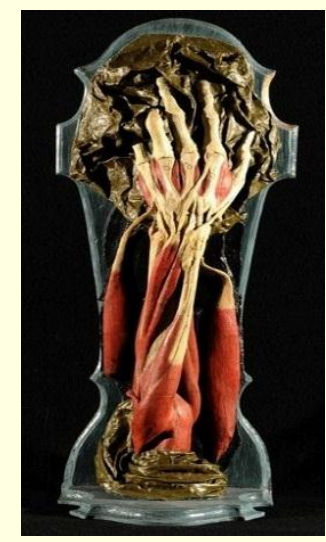

Şekil 2. Anna Morandi'nin ön kol kas sistemi ve kemik bal mumu modeli

Anna Morandi, kocasının bal mumunu bir insan kalbinin diseksiyonunu yaparken (Şekil 3), kendi bal mumunu da bir insan beyninin diseksiyonunu yaparken (Şekil 4) göstermiştir. Yaptığı bu iki eser aklı erkeklerle, duyguları kadınlarla ilişkilendiren ikilemin zıttı gibidir. ${ }^{13}$ Morandi'nin hisseden eller bal mumunda (Şekil 5), dokunmanın anatomisini açıklamak üzere bir çift el modellenmiştir. Bu ellerde birbirine zıt hisler ifade edilmiştir (ağrı ve zevk); bir iğne batırılmış sağ el, gergin bir şekilde geri çekilirken, sol el ipek bir yastığı kavramaktadır. ${ }^{10}$ Ek olarak, Anna Morandi'nin dokunma hissi üzerine şunları yazdığı belirtilmiştir; "Tespit edilen tüm sinirler parmakların zirvesine ve tepesine kadar uzanır ve burada kendilerini çok küçük ve bol dallanmalarla çoğaltırlar ... Bu nedenle... Bu his başka hiçbir yerde olmadığı kadar keskin ve hassas hale getirilir." 

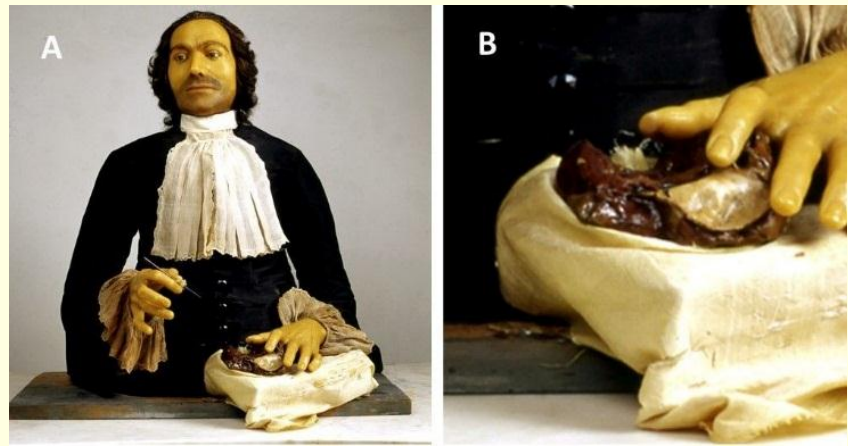

Şekil 3. Anna Morandi Manzolini'nin yaptığı Giovanni Manzolini heykeli (A) ve heykelin detayındaki kalp bal mumu modeli (B)
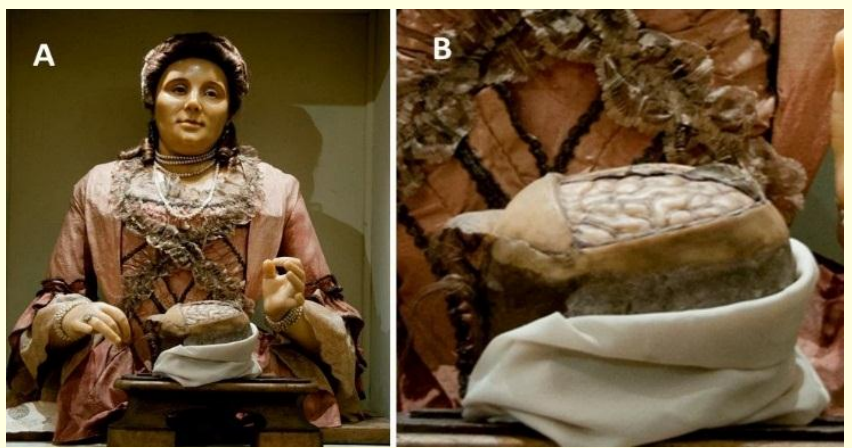

Şekil 4. Anna Morandi Manzolini'nin yaptığı kendi bal mumu heykeli (A) ve heykelin detayındaki beyin bal mumu modeli (B)

Anna Morandi'nin diseksiyon becerisi, gözdeki musculus obliquus inferior'un sonlanma yeri de dâhil olmak üzere daha önce bilinmeyen birkaç anatomik parçayı keşfetmesiyle sonuçlanmıştır. ${ }^{8}$ Göz kaslarının modellenmesi (Şekil 6), bu kasların işlevinin anlaşılmasına katkıda bulunmuştur. ${ }^{3}$ Ayrıca Şekil 7'deki bal mumu modelinin fotoğrafında görüldüğü gibi bal mumu çalışmalarında fetüsün aşamalarını ve nasıl beslendiğini de göstermiştir. ${ }^{8,14}$

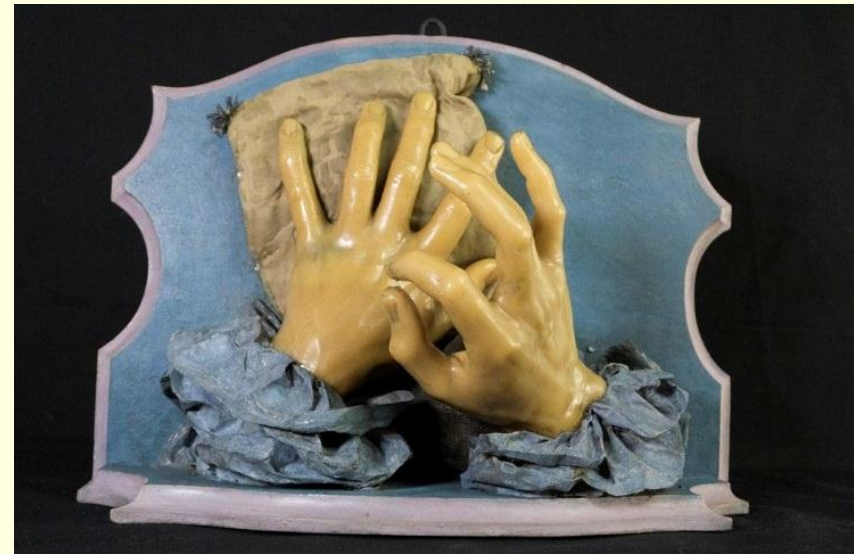

Şekil 5. Anna Morandi'nin hisseden eller bal mumu modeli (Sağ elde tutulan dikenli dal kaybolmuştur)
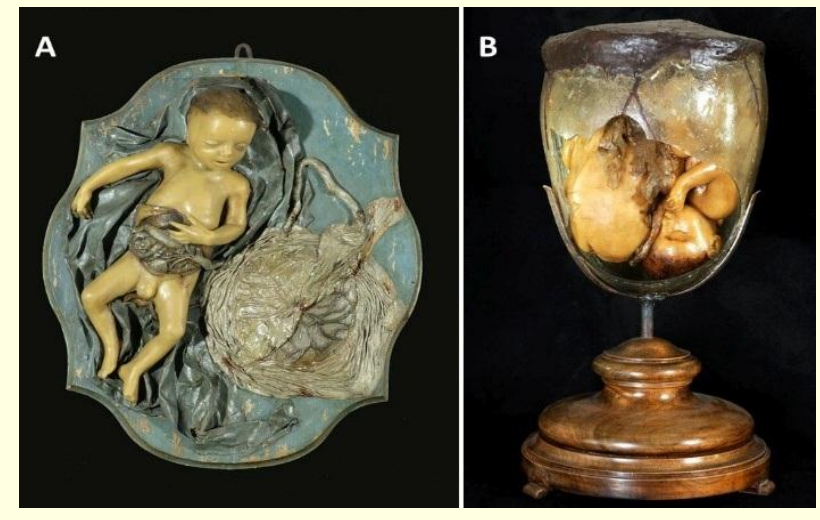

Şekil 7. Giovanni Manzolini ve Anna Morandi'nin plasentalı çocuk bal mumu modeli çalışmaları (A-B)

Bolonya Tıp Enstitüsü, 1774'te Anna Morandi'nin ölümünden sonra, yaptığı ve kullandığı bal mumu koleksiyonunu satın almıştır. Bu koleksiyon şu anda Bolonya'daki Bilim Enstitüsü'ndedir. ${ }^{8}$ Anna Morandi Manzolini tarafından yapılan, altmış bir örnek bulunmaktadır. Örnekler kulak, burun, dil, pharynx, kalp, 
akciğer, pelvis, kadın üreme organları ve fetüs dâhil olmak üzere insan vücudunun farklı bölümleriyle ilgilidir. Ayrıca görme, duyma, tat, koku ve dokunma duyularını çok gerçekçi ayrıntılarla anlatan modeller ile organların vaskülarizasyonu ve innervasyonunu vurgulayan modeller de, bu örnekler arasında bulunmaktadır (Şekil 8). Kaslar arasındaki bağlantıları gösterdiği bal mumu modeli (Şekil 9) gelişmiş bilgi birikimini yansıtmaktadır. ${ }^{12}$

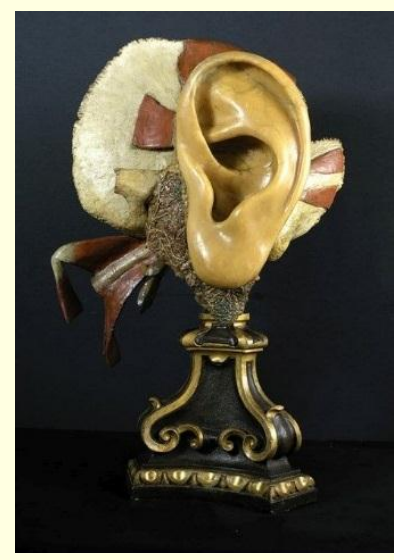

Şekil 8. Anna Morandi Manzolini'nin kulak bal mumu modeli

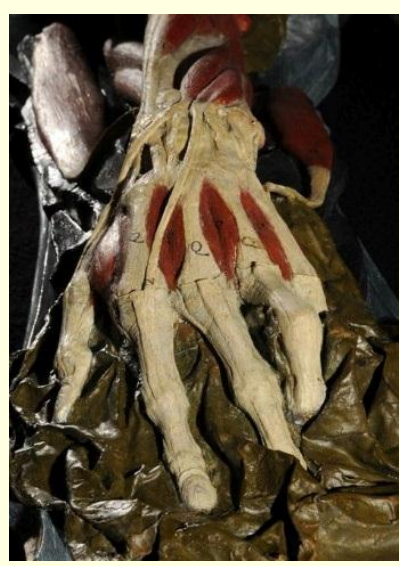

Şekil 9. Anna Morandi'nin ön kol kas sistemi ve kasların spesifik etkisinin ayrıntılı bal mumu modeli

\section{Etkileri}

Anna Morandi'nin statüsü, anatomist ve sanatçı olarak eş zamanlı rolü nedeniyle karmaşıktır. 0 , doku ve organların doğru mum modellerinin önde gelen yaratıcılarından biridir. ${ }^{6}$ Morandi'nin bal mumları, insan vücudunun işleyişini gerçekçi bir şekilde ortaya koymak ve teorileştirmek için, güzel sanatlar ve cerrahiyi birleştirerek pratik görsel ile teorik metin arasında köprü kurmaktadır. ${ }^{15}$ Morandi, çağdaş sinirbilim için gerekli olan anatomik yapıların, özellikle duyusal ve sinirsel innervasyonun yazılı ve görsel analizlerini yapmıştır. ${ }^{4}$

İsimsiz Belçikalı bir doktor 1755 'te Anna Morandi için bin kadavrayı diseke ettiğini ve Bolonya hastanesinin ona birkaç tane vermediği bir ayın geçmediğini söylemiştir. Ayrıca, yeni bir yöntem ve en son teorilerle genç öğrencilere anatomi dersleri verdiğini belirtmiştir. ${ }^{3}$ Anna Morandi, bal mumu modeli için yeni bir amaç oluşturmuş, bu modelleri doğru anatomi için bir öğretim aracı olarak sunmuştur. ${ }^{5}$ Insan vücudunun dinamik yapılarını anlatan koleksiyonları tıp öğrencilerinin eğitimine, tıp pratisyenleri ve uzmanları tarafından kullanımına hizmet etmiştir. ${ }^{10}$ Çalışmaları, seçkin Vassourie koleksiyonu ve Dr. Auzoux'un kağıt hamurundan yapılan kreasyonları gibi günümüz okullarında kullanılanların öncüsü olan modellerin ilk örneği haline gelmiştir. $^{8}$

Morandi, bal mumu modellerini, sistematik bir yaklaşımla aşamalı diseksiyona dayalı 250 sayfalık bir defter olarak düzenlemiştir. Defter şu anda Bolonya Üniversitesi kütüphanesinde bulunmaktadır. ${ }^{10,16} \mathrm{Bu}$ defterin çağdaş anatomik çalışmaların gelişimi üzerindeki etkileri oldukça büyüktür. ${ }^{10}$

\section{Sonuç}

XVIII. yüzyıl Bolonya, İtalya'da kadın bilim insanlarından Anna Morandi Manzolini'nin, anatomi çalışmalarında önemli bir öncü olduğu göze çarpmaktadır. Gelecek nesillerin onun bıraktığı kalıcı eserlerden faydalanması, bilimin ilerlemesine sunduğu büyük katkılar, bulunduğu çağın değerli bilim insanları arasında yer aldığı yönünde de bir fikir vermektedir. Aynı zamanda, insan bal mumu modellerine adanmış bir diseksiyon laboratuvarı kurması, onun ciddi bir anatomist olduğunu da ortaya koymaktadır. Yaşadığı tüm sıkıntılara rağmen vazgeçmeyen idealist kişiliğinin, araştırmacılara ilham kaynağı olacağını düşünüyoruz. 
Literatürde az sayıda çalışmada Anna Morandi Manzolini'ye yer verilmiştir. O dönemden günümüze ulaşan verilerin sınırlı olmasının, bunda bir etken olabileceğini düşünüyoruz. Anna Morandi, yaklaşık 250 yıl önce yaşamış olmasına rağmen, yararlı ve başarıı çalışmaları hala bahsedilmeye değerdir. Sonuç olarak, Anna Morandi'nin hayatının ve çalışmalarının bir parça da olsa ortaya çıkarılması tıp ve anatomi tarihi açısından büyük bir kazanım olacaktır.

\section{Bilgi}

Şekiller "Alma Mater Studiorum University of Bologna - Sistema Museale di Ateneo | ph Fulvio Simoni" tarafından 10 Şubat 2021 tarihinde verilen izin üzerine kullanılmıştır.

Bu çalışma, 28 Kasım 2020'de Ankara'da (online) TAKAD tarafından düzenlenen 21. Ulusal Anatomi Kongresi'nde sözlü bildiri olarak sunulmuştur.

Yazarlar arasında çıkar çatışması yoktur. Bu çalışma için herhangi bir kurumdan maddi destek alınmamıştır. Çalışmaya görüşleriyle katkı sağlayan SDÜ Tıp Fakültesi Anatomi Ana Bilim Dalı Başkanı Prof. Dr. Soner ALBAY'a ve SDÜ Tıp Fakültesi Tıp Tarihi ve Etik Ana Bilim Dalı Başkanı Dr. Öğr. Üyesi Fuat iNCE'ye teşekkür ederiz.

\section{Araştırmacı Katkı Oranı Beyanı}

Berfu Özdemir: Tasarım, veri toplama ve işleme, analiz ve yorum, kaynak taraması, kaynak sağlama, makale yazımı, eleştirel inceleme.

Onur Can Şanlı: Fikir, denetleme, analiz ve yorum, kaynak sağlama, eleştirel inceleme.

Ahmet Dursun: Fikir, tasarım, denetleme, danışmanlık, veri toplama ve işleme, kaynak taraması, kaynak sağlama, makale yazımı, eleştirel inceleme.

\section{Kaynaklar}

1. Bush E. A Golden Web. Bulletin of the Center for Children's Books 2010; 63(9): 395.

2. Marković D, Marković Živković B. Development of Anatomıcal Models-Chronology. Acta Medica Medianae 2010; 49(2).

3. Finucci V. The Lady Anatomist: The Life and Work of Anna Morandi Manzolini by Rebecca Messbarger. MLN 2014; 129(1): $194-6$.

4. Rosito P, et al. Anna Morandi Manzolini (1716-1774) master sculptress of anatomic wax models. Pediatr Blood Canc 2004; 42(4): 388-9.

5. Åhrén, E. The Lady Anatomist: The Life and Work of Anna Morandi Manzolini. In: Journal of the History of Medicine and Allied Sciences, Messbarger R, 68, 1, Oxford University Press, Chicago, USA, 2013; 131-3.

6. Ferry G. Anna Morandi: anatomist of Enlightenment Bologna. The Lancet 2018; 392(10145): 375.

7. Stanford K, et al. The importance of anatomy. Frontiers for Young Minds 2020; 8(546763).

8. Grinstein LS, Biermann CA, Rose RK. Women in the biological sciences: a biobibliographic sourcebook. 1, USA, Westport: Greenwood Press, 1997; 307-9.

9. Haviland TN, Parish LC. A brief account of the use of wax models in the study of medicine. Journal of the history of medicine and allied sciences 1970; 25(1): 52-75.

10. Messbarger R. Anna Morandi's Wax Self-Portrait with Brain. In: Progress in Brain Research, Finger S, Zaidel DW, Boller F, Bogousslavsky J, 203, Elsevier, St. Louis, USA, 2013, 75-93.

11. Filippelli LA, Walberg HJ. Childhood traits and conditions of eminent women scientists. Gifted Child Quarterly 1997; 41(3): 95103.

12. Maraldi NM, et al. Anatomical waxwork modeling: The history of the Bologna Anatomy Museum. The Anatomical Record: An Official Publication of the American Association of Anatomists 2000; 261(1): 5-10.

13. Elkana Y. Rethinking the Enlightenment. Approaching Religion 2011; 1(2).

14. Dacome L. Women, wax and anatomy in the 'century of things. Renaissance Studies 2007; 21(4): 522-50.

15. Messbarger R. Waxing poetic: Anna Morandi Manzolini's anatomical sculptures. Configurations 2001; 9(1): 65-97.

16. Messbarger R. Re-membering a body of work: anatomist and anatomical designer Anna Morandi Manzolini. Studies in EighteenthCentury Culture 2003; 32(1): 123-54. 